Case Report

\title{
Primary MALT Lymphoma of the Breast Treated with Definitive Radiation
}

\author{
Mohammad Hissourou III, ${ }^{1}$ Sayyad Yaseen Zia, ${ }^{2}$ Mahfood Alqatari, ${ }^{3}$ \\ James Strauchen, ${ }^{3}$ and Richard L. Bakst ${ }^{2}$ \\ ${ }^{1}$ Icahn School of Medicine at Mount Sinai, New York, NY 10029, USA \\ ${ }^{2}$ Department of Radiation Oncology, Icahn School of Medicine at Mount Sinai Hospital, New York, NY 10029, USA \\ ${ }^{3}$ Department of Pathology, Icahn School of Medicine at Mount Sinai, New York, NY 10029, USA
}

Correspondence should be addressed to Mohammad Hissourou III; mohammad.hissourou@icahn.mssm.edu

Received 11 February 2016; Revised 14 April 2016; Accepted 17 April 2016

Academic Editor: Gandhi Damaj

Copyright (C) 2016 Mohammad Hissourou III et al. This is an open access article distributed under the Creative Commons Attribution License, which permits unrestricted use, distribution, and reproduction in any medium, provided the original work is properly cited.

We are reporting a case of a 59-year-old woman, with a family history of breast cancer, who presented with extranodal marginal zone lymphoma (MALT) of the left breast. She received definitive radiation therapy and remains without evidence of disease. Here, we present a case and review the current literature to determine the optimal treatment of this rare presentation of MALT.

\section{Introduction}

Mucosa-associated lymphoid tissue (MALT) lymphomas are extranodal B cell lymphomas and a type of marginal zone lymphoma. The most common sites of MALT lymphomas are the stomach, spleen, and the eye/adnexa. MALT lymphomas of the breast are exceedingly rare. It has been hypothesized that the rarity of primary breast lymphomas, which account for just $0.4-0.5 \%$ of all breast malignancies and $1.7-2.2 \%$ of all extranodal lymphomas, is due to the scarcity of mucosaassociated lymphoid tissue in the breast $[1,2]$. We report a case of primary breast MALT and we review the currently available literature on etiology, pathogenesis, diagnosis, prognosis, and treatment of this rare manifestation of a MALT.

\section{Case Report}

The patient has been undergoing routine screening mammograms since the age of 40 . On her annual screening mammogram, a $9 \mathrm{~mm}$ left breast mass was noted. She underwent a stereotactic core biopsy, which demonstrated an expansion of B cells found in irregularly shaped aggregates, which were associated with disrupted follicular dendritic cell meshworks. The $\mathrm{B}$ cells were $\mathrm{CD} 20$ positive, but negative for $\mathrm{CD} 5, \mathrm{CD} 10$, and BCL6; these findings were consistent with MALT of the breast (Figure 1).

The patient underwent staging workup, which included positron emission tomography (PET) imaging, computerized topography (CT) imaging, and a bone marrow biopsy. The PET scan showed mild uptake in an $8 \mathrm{~mm}$ left breast nodule (Figure 2(a)). Bone marrow biopsy was negative. The patient denied any B-symptoms and was staged as IAE MALT lymphoma of the breast.

Treatment options were discussed, including lumpectomy and definitive radiation therapy. The patient elected definitive radiation therapy. The patient received definitive 3D conformational radiation therapy treatment to a total dose of $3000 \mathrm{cGy}$ in 15 fractions (Figure 3). The treatment included the PET positive area with a small margin; the patient experienced no toxicity, including dermatitis, due to the minimally involved treatment area. At her three-month follow-up, she had no evidence of disease (Figure 2(b)).

\section{Discussion}

Non-Hodgkin lymphomas (NHL) are malignancies that originate in lymphoid tissue and arise from T cells, B cells, and natural killer (NK) cells, with MALTs representing only $5 \%$ 


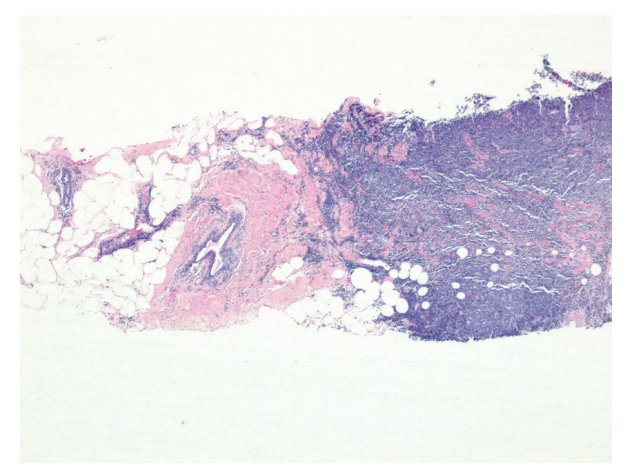

(a)

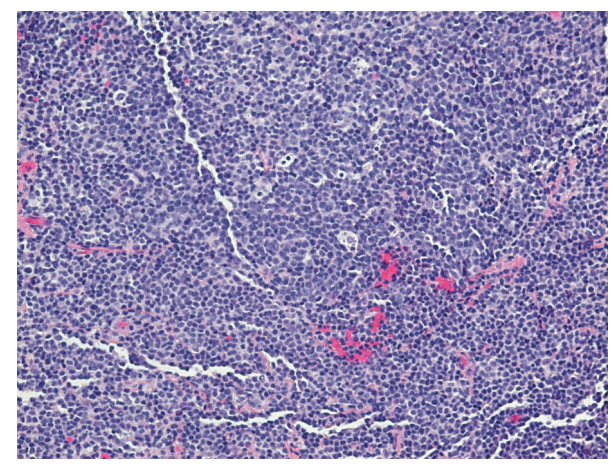

(b)

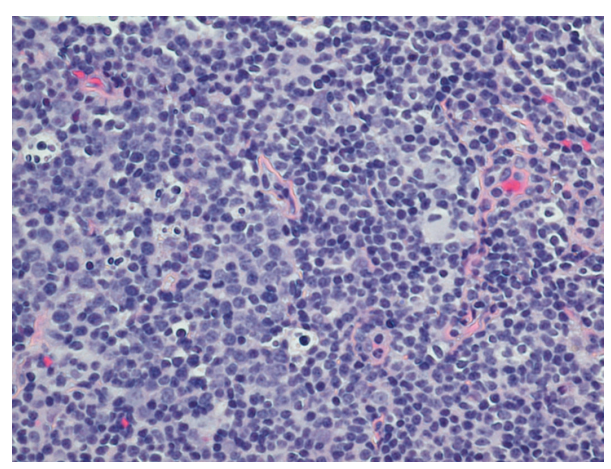

(c)

FIGURE 1: Low and high power images of H\&E stain show infiltration of the breast tissue by lymphocytes of MALT lymphoma. These lymphocytes have abundant pale cytoplasm leading to monocytoid features.

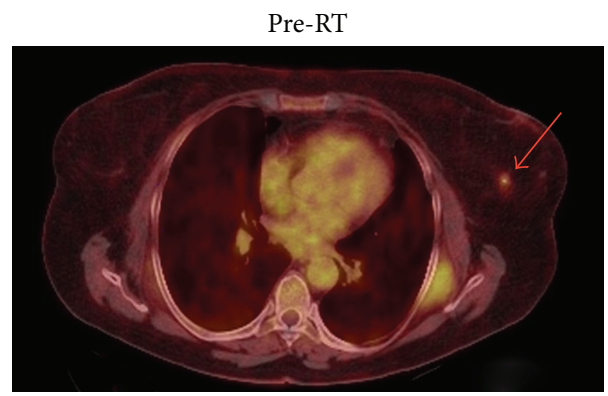

(a)

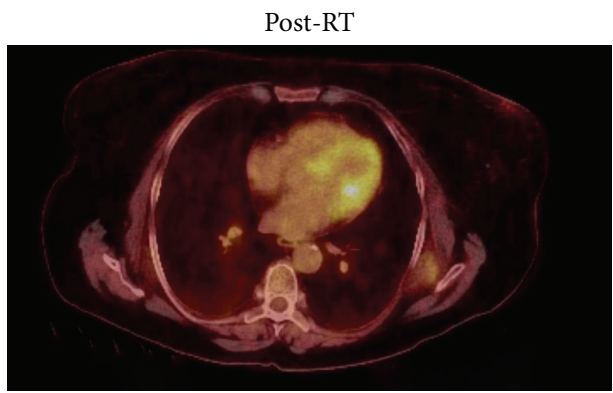

(b)

FIgURE 2: Pretreatment axial PET showing left breast mass with avidity in the left breast (a) and posttreatment axial PET showing complete response with no avidity present in the left breast (b).

of all NHL [3]. The etiology of NHL is poorly understood; however, the most significant risk factor for development of all NHL is immunodeficiency [4]. Interestingly, MALT lymphomas specifically have been associated with robust, prolonged inflammation in the case of Helicobacter pylori infection and with chronic immune system dysregulation in the case of Sjögren's syndrome and Hashimoto's thyroiditis [5-8].

The precise mechanism of the pathogenesis of breast MALT is not known; however, there is a hypothesis that sex hormones modulate immune function and the development of NHL. Nevertheless, findings concerning the specific role of estrogen in the development of NHL as a whole are mixed; some studies have found no effect, while others have found a protective or contributory effect [9-11]. Further research on the proliferative effects of estrogen in malignant conditions could be beneficial in the development of new treatments; there is some current evidence to support the proposition that estrogen receptor $\beta$ may modulate the proliferative effects of estrogen receptor $\alpha$ [12]. Further research on the balance between proliferative $(\mathrm{ER} \alpha)$ and antiproliferative $(\mathrm{ER} \beta)$ effects of estrogen receptors could lead to new NHL cancer treatments.

Patients with breast MALT may present with a unilateral palpable mass; however, most patients will be otherwise asymptomatic, including absence of classic B-symptoms 
s
ơ
辛

Ұ

है
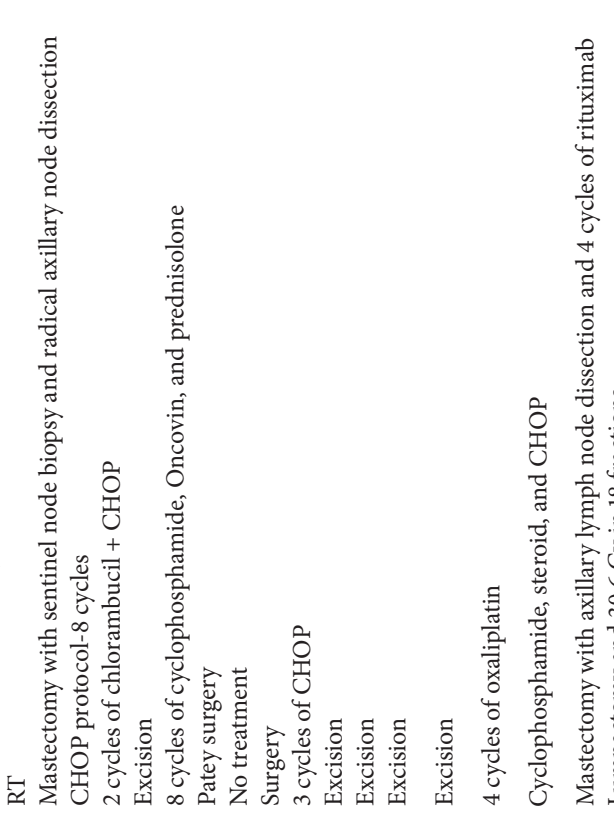

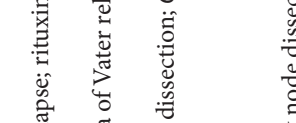

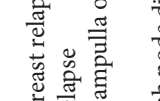

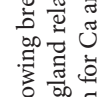

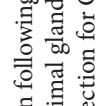

总爱 总

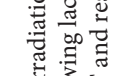

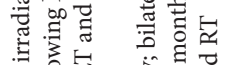

急宫安

要

政

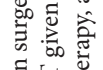

等

石 흉

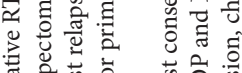

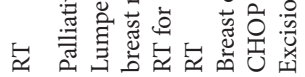

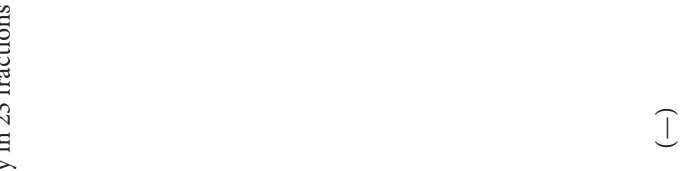

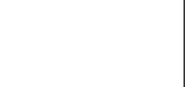

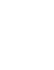

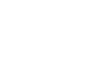

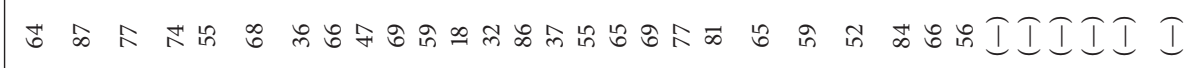

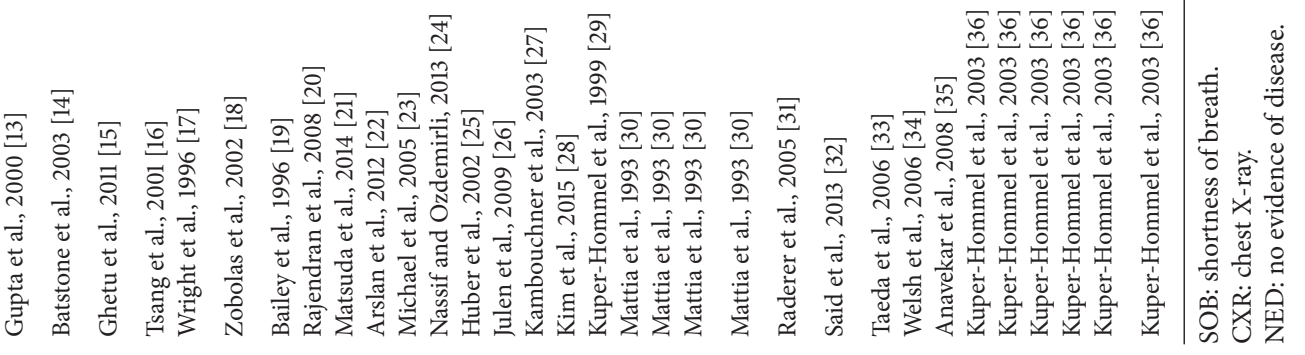




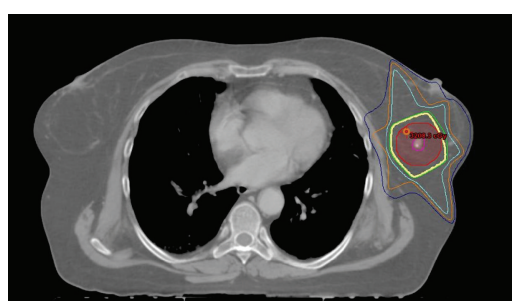

(a)

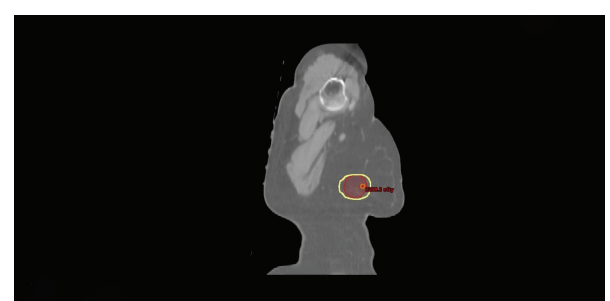

(b)

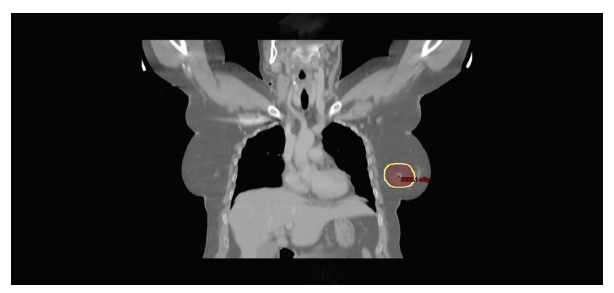

(c)

FIGURE 3: 3D conformation radiation therapy planning of MALT breast lymphoma. Dose distribution in the axial (a), sagittal (b), and (c) coronal planes. The red area indicates the planning target volume (PTV) and the yellow line indicates the 30 Gy isodose line.

$[37,38]$. In a retrospective study of lymphomatous disease of the breast, the overwhelming majority of patients detected their disease by palpation of a breast mass rather than mammography [39]. Routine mammography may be useful in detecting MALTs. Once a diagnosis of MALT is established, the standard lymphoma workup including bone marrow analysis should be performed.

The prognosis of patients affected by breast MALT will depend, in part, on their clinical stage. Additional predictive factors include age, number of extranodal sites, performance status, and LDH levels. The treatment for primary breast lymphoma is not yet fully established. However, for localized MALT lymphomas, radiation therapy alone can be used as the definitive treatment. For localized breast MALT, local radiation therapy, such as involved field radiation therapy, and a moderate dose of 25-30 Gy are recommended [40, 41]. Treatment guidelines by the International Lymphoma Radiation Oncology Group report a recommendation for whole breast radiation therapy, noting that partial breast radiation can be considered in some cases; in our case, we opted for partial breast radiation given the small tumor size in relation to her breast [42]. Local radiation therapy can yield control rates and overall-survival rates over 90\% [37]. For our patient, we used involved site radiation therapy to a total dose of 30 Gy with excellent results; the patient had no evidence of disease at her 3-month follow-up.

For patients with disseminated disease, treatment options may include a watch-and-wait approach, biological therapy, and/or chemotherapy. Since tumors are generally highly receptive to radiation therapy and chemotherapy, mastectomy need not be considered and wide excision is not necessary in the majority of cases [37]. Table 1 summarizes treatment management for all reported cases of breast MALT lymphoma to date. Of 32 patients, 5 were treated with definitive radiation therapy, 1 patient received palliative radiation therapy, 1 patient received no treatment,
6 patients received chemotherapy alone, and 19 patients received surgery (either surgery alone or surgery in addition to chemotherapy, radiation therapy, or both). Of those that received definitive RT therapy, none died from progressive disease. Of the 6 patients who received chemotherapy alone, 1 died of progressive disease. Of the 19 patients who received surgery, 2 died of progressive disease. These findings further support the recommendation for definitive radiation therapy as a reasonable treatment option for breast MALT.

For MALT lymphomas treated with radiation therapy as the sole treatment modality, relapse rarely occurs distantly [43]. If the patient's cancer was detected by mammography, they should continue to undergo annual screening. They should also be counseled on secondary malignancy and risk of coronary artery disease depending on the dose to the heart.

In summary, breast MALTs are generally an indolent disease with an asymptomatic presentation, including absence of B-symptoms. For localized disease, definitive radiation represents a reasonable treatment option with excellent response, local control, and minimal toxicity.

\section{Competing Interests}

The authors declare that there are no competing interests regarding the publication of this paper.

\section{References}

[1] M. Topalovski, D. Crisan, and J. C. Mattson, "Lymphoma of the breast: a clinicopathologic study of primary and secondary cases," Archives of Pathology and Laboratory Medicine, vol. 123, no. 12, pp. 1208-1218, 1999.

[2] M. O. Khalil, L. M. Morton, S. S. Devesa et al., "Incidence of marginal zone lymphoma in the United States, 2001-2009 with a focus on primary anatomic site," British Journal of Haematology, vol. 165, no. 1, pp. 67-77, 2014. 
[3] J. O. Armitage and D. D. Weisenburger, "New approach to classifying non-Hodgkin's lymphomas: clinical features of the major histologic subtypes. Non-Hodgkin's Lymphoma Classification Project," Journal of Clinical Oncology, vol. 16, no. 8, pp. 27802795, 1998.

[4] B. C. Chiu and D. D. Weisenburger, "An update of the epidemiology of non-Hodgkin's lymphoma," Clinical Lymphoma, vol. 4, no. 3, pp. 161-168, 2003.

[5] K. E. Smedby, E. Baecklund, and J. Askling, "Malignant lymphomas in autoimmunity and inflammation: a review of risks, risk factors, and lymphoma characteristics," Cancer Epidemiology Biomarkers \& Prevention, vol. 15, no. 11, pp. 2069-2077, 2006.

[6] J. Parsonnet, S. Hansen, L. Rodriguez et al., "Helicobacter pylori infection and gastric lymphoma," The New England Journal of Medicine, vol. 330, no. 18, pp. 1267-1271, 1994.

[7] R. J. Bende, F. Van Maldegem, and C. J. M. Van Noesel, “Chronic inflammatory disease, lymphoid tissue neogenesis and extranodal marginal zone B-cell lymphomas," Haematologica, vol. 94, no. 8, pp. 1109-1123, 2009.

[8] E. Hyjek and P. G. Isaacson, "Primary B cell lymphoma of the thyroid and its relationship to Hashimoto's Thyroiditis," Human Pathology, vol. 19, no. 11, pp. 1315-1326, 1988.

[9] M. Nørgaard, A. H. Poulsen, L. Pedersen et al., "Use of postmenopausal hormone replacement therapy and risk of nonHodgkin's lymphoma: a Danish population-based cohort study," British Journal of Cancer, vol. 94, no. 9, pp. 1339-1341, 2006.

[10] K. H. Mildon, P. Ansell, E. Roman, and E. V. Kane, "Reproductive factors, menopausal hormone therapy, and risk of nonHodgkin, diffuse large B-cell and follicular lymphomas: a UK case-control study," Cancer Causes \& Control, vol. 21, no. 12, pp. 2079-2083, 2010.

[11] E. Fernandez, S. Gallus, C. Bosetti, S. Franceschi, E. Negri, and C. La Vecchia, "Hormone replacement therapy and cancer risk: a systematic analysis from a network of case-control studies," International Journal of Cancer, vol. 105, no. 3, pp. 408-412, 2003.

[12] M. M. Liu, C. Albanese, C. M. Anderson et al., "Opposing action of estrogen receptors alpha and beta on cyclin D1 gene expression," The Journal of Biological Chemistry, vol. 277, no. 27, pp. 24353-24360, 2002.

[13] D. Gupta, V. Shidham, V. Zemba-Palko, and A. Keshgegian, "Primary bilateral mucosa-associated lymphoid tissue lymphoma of the breast with atypical ductal hyperplasia and localized amyloidosis. A case report and review of the literature," Archives of Pathology and Laboratory Medicine, vol. 124, no. 8, pp. 1233-1236, 2000.

[14] P. Batstone, L. Forsyth, and J. R. Goodlad, "Cytogenetic evidence for the origin of neoplastic cells in CD5-positive marginal zone B-cell lymphoma," Human Pathology, vol. 34, no. 10, pp. 10651067, 2003.

[15] D. Ghetu, V. Membrez, A. Bregy et al., "Expect the unexpected: primary breast MALT lymphoma," Archives of Gynecology and Obstetrics, vol. 284, no. 5, pp. 1323-1324, 2011.

[16] R. W. Tsang, M. K. Gospodarowicz, M. Pintilie et al., "Stage I and II malt lymphoma: results of treatment with radiotherapy," International Journal of Radiation Oncology Biology Physics, vol. 50, no. 5, pp. 1258-1264, 2001.

[17] M. Wright, H. Maclean, and J. Ironside, "Metachronous lymphoma of the breast and conjunctiva," The British Journal of Ophthalmology, vol. 80, no. 6, article 574, 1996.
[18] B. Zobolas, G. H. Sakorafas, I. Kourakli, and A. G. Tsiotou, "Bilateral, primary, low-grade, diffuse B-cell lymphoma of mucosa-associated lymphoid tissue (MALT) of the breast," Breast Journal, vol. 8, no. 6, p. 382, 2002.

[19] E. M. Bailey, J. A. Ferry, N. L. Harris, M. C. Mihm Jr., J. O. Jacobson, and L. M. Duncan, "Marginal zone lymphoma (lowgrade B-cell lymphoma of mucosa-associated lymphoid tissue type) of skin and subcutaneous tissue: a study of 15 patients," The American Journal of Surgical Pathology, vol. 20, no. 8, pp. 1011-1023, 1996.

[20] R. R. Rajendran, J. P. Palazzo, G. F. Schwartz, J. H. Glick, and L. J. Solin, "Primary mucosa-associated lymphoid tissue lymphoma of the breast," Clinical Breast Cancer, vol. 8, no. 2, pp. 187-188, 2008.

[21] I. Matsuda, T. Watanabe, Y. Enomoto, Y. Takatsuka, Y. Miyoshi, and S. Hirota, "Spontaneous regression of primary extranodal marginal zone lymphoma of mucosa-associated lymphoid tissue (MALT lymphoma) colliding with invasive ductal carcinoma of the breast: a case report," International Journal of Clinical and Experimental Pathology, vol. 7, no. 10, pp. 70207027, 2014.

[22] S. H. Arslan, U. Uyeturk, E. Tekgunduz et al., "Primary breast Mucosa-Associated Lymphoid Tissue (MALT) lymphoma transformation to diffuse large B-cell lymphoma: a case report," Turkish Journal of Hematology, vol. 29, no. 3, pp. 274277, 2012.

[23] C. W. Michael, P. H. Richardson, and C. W. Boudreaux, "Pulmonary lymphoma of the mucosa-associated lymphoid tissue type: report of a case with cytological, histological, immunophenotypical correlation, and review of the literature," Annals of Diagnostic Pathology, vol. 9, no. 3, pp. 148-152, 2005.

[24] S. Nassif and M. Ozdemirli, "EBV-positive low-grade marginal zone lymphoma in the breast with massive amyloid deposition arising in a heart transplant patient: a report of an unusual case," Pediatric Transplantation, vol. 17, no. 6, pp. E141-E145, 2013.

[25] S. Huber, M. Vesely, M. Medl, and H. Czembirek, "Lowgrade mucosa-associated lymphoma of the breast: radiologicalpathological correlation," European Radiology, vol. 12, no. 5, pp. 1093-1096, 2002.

[26] O. Julen, I. Dellacasa, M. F. Pelte et al., "Primary breast lymphomas," Rare Tumors, vol. 1, no. 1, article e14, 2009.

[27] M. Kambouchner, P. Godmer, L. Guillevin, M. Raphaël, D. Droz, and A. Martin, "Low grade marginal zone B cell lymphoma of the breast associated with localised amyloidosis and corpora amylacea in a woman with long standing primary Sjögren's syndrome," Journal of Clinical Pathology, vol. 56, no. 1, pp. 74-77, 2003.

[28] D.-H. Kim, J. Y. Jeong, S.-W. Lee, J. Lee, and B.-C. Ahn, "18F-FDG PET/CT finding of bilateral primary breast mucosaassociated lymphoid tissue lymphoma," Clinical Nuclear Medicine, vol. 40, no. 2, pp. el48-e149, 2015.

[29] M. J. J. Kuper-Hommel, L. W. Vrints, J. W. W. Coebergh, and G. Vreugdenhil, "High grade MALT-lymphoma of the breast," Netherlands Journal of Medicine, vol. 54, no. 6, pp. 235-238, 1999.

[30] A. R. Mattia, J. A. Ferry, and N. L. Harris, "Breast lymphoma: a B-cell spectrum including the low grade B-cell lymphoma of mucosa associated lymphoid tissue," American Journal of Surgical Pathology, vol. 17, no. 6, pp. 574-587, 1993.

[31] M. Raderer, S. Wöhrer, R. Bartsch et al., "Phase II study of oxaliplatin for treatment of patients with mucosa-associated 
lymphoid tissue lymphoma," Journal of Clinical Oncology, vol. 23, no. 33, pp. 8442-8446, 2005.

[32] S. M. Said, C. Reynolds, R. E. Jimenez et al., "Amyloidosis of the breast: predominantly AL type and over half have concurrent breast hematologic disorders," Modern Pathology, vol. 26, no. 2, pp. 232-238, 2013.

[33] Y. Taeda, N. Ariga, K. Okamura et al., "Primary breast mucosaassociated lymphoid tissue (MALT) lymphoma with highgrade transformation evidenced by prominent lymphoepithelial lesions," Breast Cancer, vol. 13, no. 3, pp. 322-327, 2006.

[34] J. S. Welsh, A. Howard, H. Y. Hong, D. Lucas, T. Ho, and D. J. Reding, "Synchronous bilateral breast mucosa-associated lymphoid tissue lymphomas addressed with primary radiation therapy," American Journal of Clinical Oncology, vol. 29, no. 6, pp. 634-635, 2006.

[35] N. S. Anavekar, W. M. Rozen, K. Rowe, and C. Murphy, "Synchronous carcinoma and lymphoma of the breast," Clinical Breast Cancer, vol. 8, no. 3, pp. 281-284, 2008.

[36] M. J. J. Kuper-Hommel, S. Snijder, M. L. G. Janssen-Heijnen et al., "Treatment and survival of 38 female breast lymphomas: a population-based study with clinical and pathological reviews," Annals of Hematology, vol. 82, no. 7, pp. 397-404, 2003.

[37] F. Bertoni and E. Zucca, "State-of-the-art therapeutics: marginal-zone lymphoma," Journal of Clinical Oncology, vol. 23, no. 26, pp. 6415-6420, 2005.

[38] E. Zucca, A. Conconi, E. Pedrinis et al., "Nongastric marginal zone B-cell lymphoma of mucosa-associated lymphoid tissue," Blood, vol. 101, no. 7, pp. 2489-2495, 2003.

[39] S. M. Domchek, J. L. Hecht, M. D. Fleming, G. S. Pinkus, and G. P. Canellos, "Lymphomas of the breast: primary and secondary involvement," Cancer, vol. 94, no. 1, pp. 6-13, 2002.

[40] K. Rock, G. Rangaswamy, S. O’Sullivan, and J. Coffey, "An unusual case of marginal zone B-cell lymphoma arising in the breast-its diagnosis and the role of radiotherapy in its management," Breast Care, vol. 6, no. 5, pp. 391-393, 2011.

[41] R. W. Tsang, M. K. Gospodarowicz, M. Pintilie et al., "Localized mucosa-associated lymphoid tissue lymphoma treated with radiation therapy has excellent clinical outcome," Journal of Clinical Oncology, vol. 21, no. 22, pp. 4157-4164, 2003.

[42] J. Yahalom, T. Illidge, L. Specht et al., "Modern radiation therapy for extranodal lymphomas: field and dose guidelines from the international lymphoma radiation oncology group," International Journal of Radiation Oncology Biology Physics, vol. 92, no. 1, pp. 11-31, 2015.

[43] S. Teckie, S. Qi, S. Lovie et al., "Long-term outcomes and patterns of relapse of early-stage extranodal marginal zone lymphoma treated with radiation therapy with curative intent," International Journal of Radiation Oncology Biology Physics, vol. 92, no. 1, pp. 130-137, 2015. 


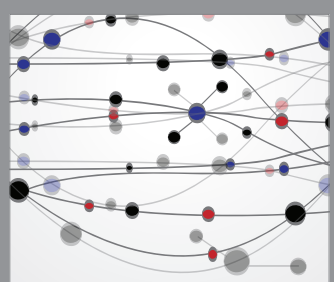

The Scientific World Journal
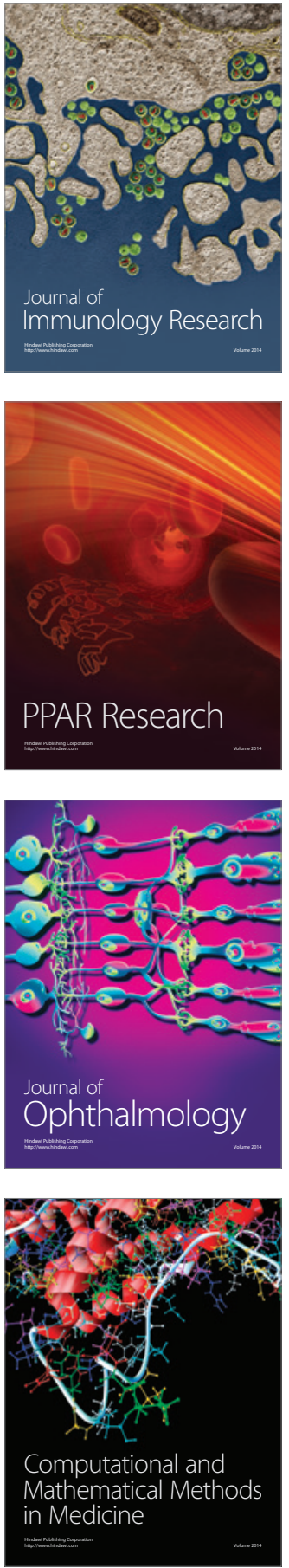

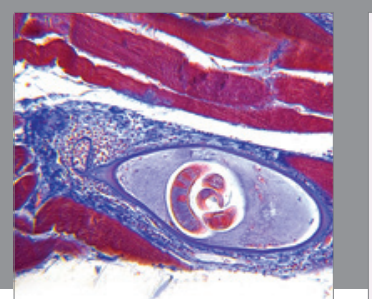

Gastroenterology Research and Practice

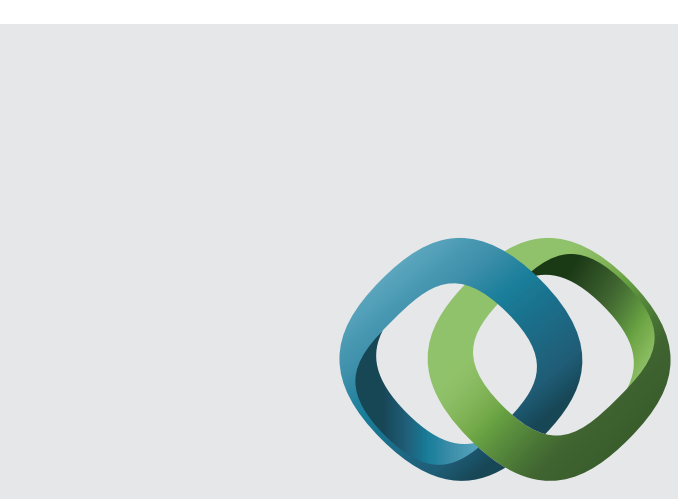

\section{Hindawi}

Submit your manuscripts at

http://www.hindawi.com
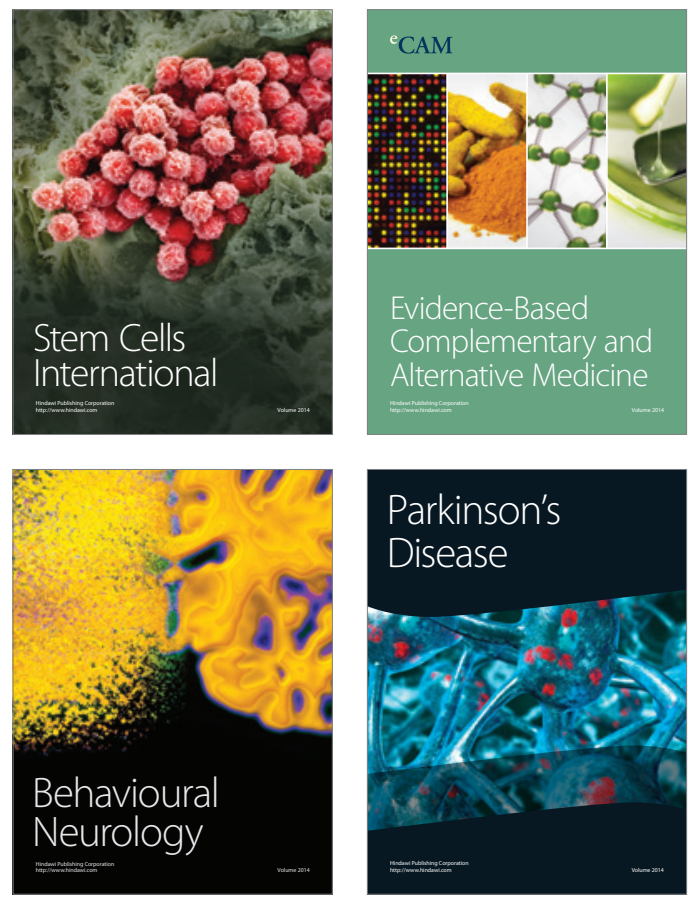
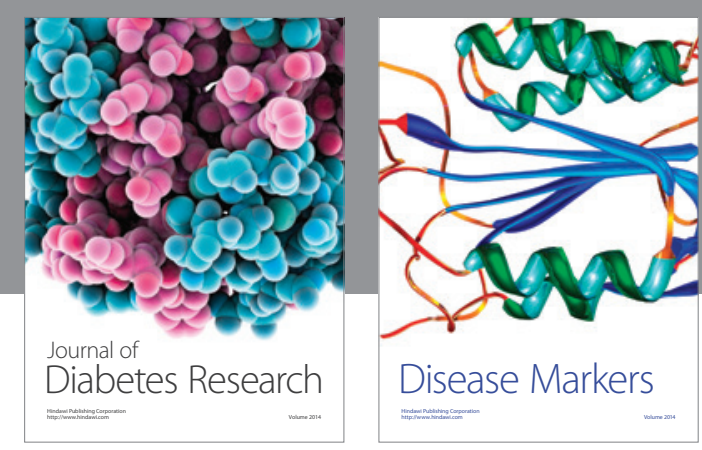

Disease Markers
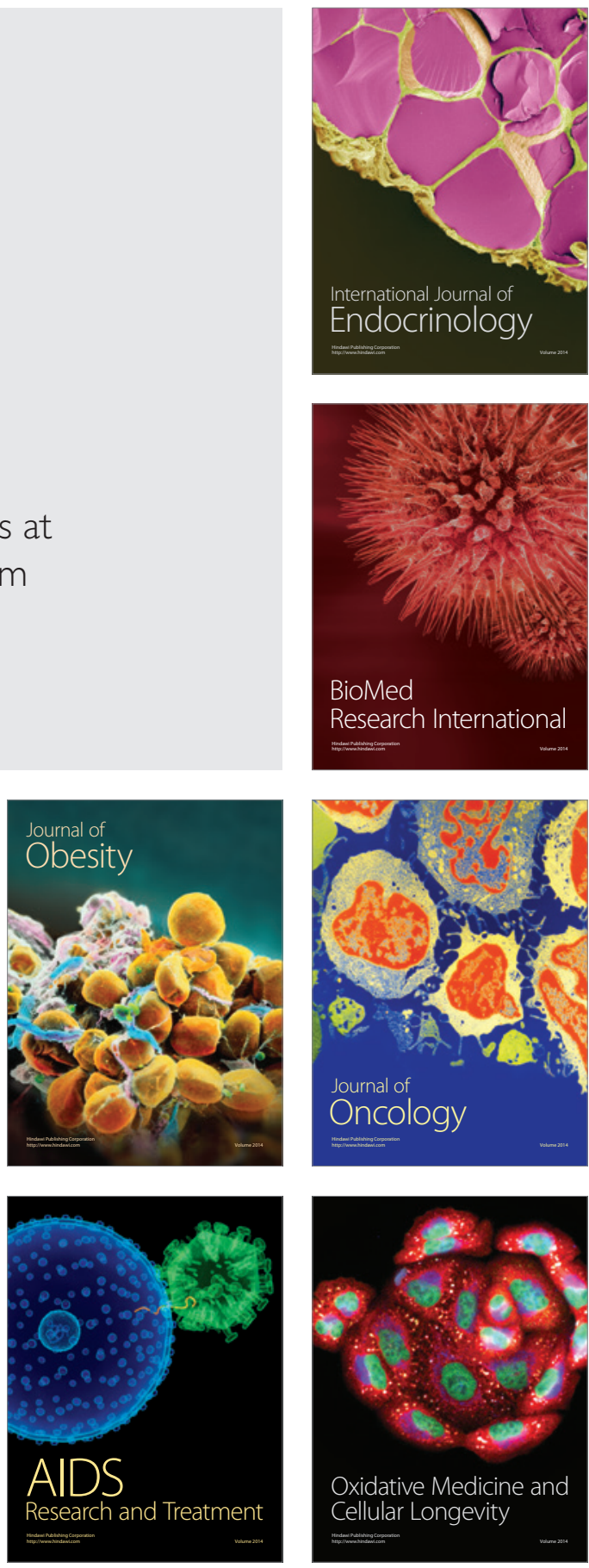